\title{
An open letter to the Health and Safety Executive
}

\author{
Michael Ashburner of the Department of Genetics at the University of \\ Cambridge gives his view on the UK Health and Safety Executive's recent \\ proposals for regulating genetic manipulation experiments
}

Dear Sirs,

The Health and Safety Executive is, I hope, engaging in that popular sport, kite flying. Worried, perhaps, by the mutant monsters so vividly portrayed on television every Saturday evening in Dr Who, you write, in your recent Consultative Document "Compulsory Notification of Proposed Genetic Experiments in the Manipulation of Microorganisms":

No person shall carry on any activity intended to alter or likely to alter the genetic constitution of any microorganism unless he has given to the Health and Safety Executive notice, in a form approved by the Executive for the purposes of these Regulations, of his intention to carry on that activity (Draft Regulation 2 of the Health and Safety (Genetic Manipulations) Regulations 1976). (my italics).

Two recent UK Government reports, those of the Working Parties chaired by Lord Ashby (Cmnd 5880; January 1975) and Professor Sir Robert Williams (Cmnd 6600; August 1976), have considered the problems posed by the recent advances in molecular biology that make it possible to introduce, in a form in which it may replicate and perhaps be transcribed and translated, DNA from "foreign" organisms (including man) into microbial hosts. Both reports considered that such experiments may lead to great social benefit but that they may be dangerous. In view of the potential dangers of some experiments of this type the Williams' Report drafted a Code of Practice to be adhered to when doing such work. This Code lays down "containment" procedures of varying levels of severity to be used for different types of experiment. In effect this will mean that because of the cost of such facilities, these experiments will be done in relatively few laboratories under the strictest supervision.

As you know, the scientific community (a pompous but useful term) is deeply divided concerning the problems that might arise from the use of these new techniques. However, the "moderate" view is probably that the recommendations of the Williams Report (and their equivalents in the USA) are reasonable and, until we know more about the reality of the dangers, will have to be lived with. Your draft regulation is, I understand, an attempt to give the Code of Practice legal teeth and to place its administration in the hands of the Health and Safety Executive.

The Advisory Group recommended by Williams would play a subservient role to the Health and Safety Executive, despite the fact that this Group alone would include not only technically competent scientists but also "individuals able to take account of the interests of employees and the general public". A central feature of the Advisory Group is that it would "command the respect of the public as well as of the scientific community". If the advice that such a group gives can be overridden by you it would certainly lose this respect and be weakened as a result. The need for the Advisory Group is not simply, as you imply, so that the scientists would not suffer from "unnecessary delay". It is envisaged as taking on a far more important role, independently referring experimental protocols and serving as a channel by means of which new safety features can quickly reach those most directly concerned, in the laboratory.

Of course a weakness of the Williams report is that scant attention is paid to the problems that arise if such techniques come to be widespread in industry. It would make little sense if academic scientists submitted to an essentially voluntary control and industrial scientists were either not controlled or had to submit to a legal control. Accepting that some form of control is required and that this control applies equally to industry, universities and so on-a by no means universal view-the question is: how best should it be applied? Your answers to this question are your draft regulations. I wish to point out that these regulations, especially regulation 2 , are bad from three points of view.

- You remove the Advisory Group or any similar body from any central role in the dialogue that must exist between those who do the experiments and those who administer the laws under which they are done. With respect, sir, you do not have the standing in the scientific community required for this job.

- Instead of being content with covering just the "genetic engineering" experiments your draft regulation would control the whole of microbial genetics. You do this despite the lack of any evidence that such control is required to protect public health and safety. The consequences of wording the regulation in this way are very serious. It would make innovation in this important field of study very difficult indeed. Furthermore, the burden on a scientist communicating with you in advance the protocol of his every experiment, for no obvious reason, would be so great that you would lose the confidence and goodwill of the scientific community. If this were to happen the dangers might be very real since you rely upon this community to draw both real and potential hazards to your attention. Remember that it was the scientists who made possible the "genetic engineering" experiments who brought their concern to public attention (Nature 250, 175). If a result of the public debate so actively encouraged by them is that scientists find their day to day activities encumbered with endless red tape, some may be reluctant to speak out quite so publically in the future-and that couli lead to a disaster that any subsequent legal process could do little to remedy. It would be a tragedy if certain types of scientific work were driven "underground" as a consequence of a ridiculous regulation.

- The third reason that the draft regulation 2 is bad is that it is unenforceable. A regulation that cannot be enforced would be evaded, at first perhaps not in ways that would present any danger to health or safety, but 
eventually by falling into general disrepute and perhaps being ignored totally. It is unenforceable because you would not be able to assess the mountain of forms that would descend upon you, and you would have grave difficulties in drawing a legal line between micro- and "macroorganisms". To enforce it rigidly would also require you to halt many quite "normal" human activities-for example the examination or treatment of people with $\mathrm{X}$-rays (surely likely to alter the genetic constitution of microorganisms to which we are hosts), and the treatment of crops with chemicals (which even if they do not alter the genetic constitution of individual microorganisms will surely alter the constitution of populations of microorganisms). Finally, it makes a nonsense of the evolutionary process: populations of all microorganisms are continuously changing their genetic constitutions and have been doing so since, quite literally, the origin of life. I fear that no law will stop this vast activity.

It is just not good enough to expect scientists to identify techniques (and organisms?) which may be excluded from regulation because they do not present "any potential hazard". Not only is the range of organisms studied so wide, it is impossible to prove that any human activity is completely safe under any circumstances. Dangerous activities, on the other hand, can usually be positively identified. Whether you list activities to be excluded from the regulations or just those to be included, the regulations will have to be continuously amended to take the results of research into account.

It would be far more effective to draft the regulations to include only those techniques of known danger or which scientists judge to be of potential danger, and actively to involve both the scientific community and others in both the assessment of these dangers and the administration of the law itself. Yours sincerely,

Michael Ashburner

\section{An open reply from the Director of the Executive}

John Locke, Director of the Health and Safety Executive, takes up the points in Michael Ashburner's letter

Dear Dr Ashburner,

I am glad to have this opportunity of commenting on the points raised by you.

The Government and the Health and Safety Commission have both accepted what you call the "moderate" view that the recommendations of the Williams Report are reasonable. This means that the carrying out of the techniques described in shorthand as "genetic engineering" should be permitted where they offer prospects of social benefit, provided that adequate steps are taken to protect workers in the laboratories and people outside those laboratories from harm. The Williams Committee recommended that in order to achieve this protection those using these techniques, whether in official laboratories or in universities or in industrial firms, should be required to notify their intentions and to seek the advice of the Advisory Group which is being set up by the Government.

The proposals for Regulations, circulated for comment by the Health and Safety Commission, are intended to cstablish this requirement to notify. The Commission does not believe that it would be right in a matter of this importance to leave people free to decide whether to abide by the recommendations of the Williams Committee. They believe that everybody should be placed in the same position of being required to give this notification.

The draft Regulations provide for notification to the Health and Safety Executive because we are a statutory body whereas the Advisory Group will have no statutory status. But I really must protest at the suggestion that the Advisory Group would play a subservient role to the Health and Safety Executive. This is simply not the case. It will be for the Advisory Group to lay down the conditions which need to be observed to enable the experiments to proceed safely. Our aim will be to make sure that the Advisory Group is in fact consulted, and secondly to make sure that its recommendations are followed. Both steps are necessary if workers and the general public are to be adequately protected and this is a responsibility placed upon us by Parliament.

Nothing in the Regulations therefore will remove the Advisory Group from its central role in the dialogue between those who wish to carry out experimentation of this kind and those who are competent to advise on the nature of the precautions which need to be taken.

The main point which you raise is that the proposed Regulations are drawn too widely and would catch many activities which do not present special hazards and which were not dealt with by the Williams Committee. This is certainly true. But the Williams Committee clearly found it very difficult to produce a precise description of the kind of work which they wanted reported. And it is no good at all saying that scientists shall notify their intention of carrying out certain types of work unless they are told pretty precisely what is to be covered.

We hope that as a result of comments on the proposed Regulations, we may be able to suggest a definition of what is to be notified, which, as you say, will cover all those types of work which could present special hazards and require special controls, and which will not be exposed to some of the kinds of objections raised in your note. I entirely agree that neither we nor the Advisory Group should be subjected to "mountains of forms". On the other hand, I am sure you would agree that we must not devise a definition of what is to he notified which would leave out certain types of work which might prove to present special hazards. It seems to us we must err, if we err at all, on the side of having rather more than we want notified rather than too little.

I hope therefore that all those concerned in this field will help us with devising a definition of the activities to be notified to the Advisory Group and to my Executive which will be sensible, workable, and capable of offering the protection to which workers and the general public are entitled.

Yours faithfully, J. H. Locke 